\title{
Effect of Friction Dampers on Seismic Response of Steel Frames
}

\author{
Ionuț-Sergiu Oance and Sunai Gelmambet
}

\begin{abstract}
This paper deals with effect of friction dampers on seismic response of 2D steel frames in comparison with structures stiffened by large sections and centrally braced. For the present study three structures with six storeys are subjected to a time history analysis. To study the effect of dampers in structures in comparison with structures stiffened by large sections and centrally braced, are analysed the relative level displacements, maximum displacement on the top, variation of lateral acceleration at the last level and variation of the maximum seismic base shear force depending on the lateral rigidity. The results indicate that placement of friction dampers improve the response of structures in all analyzed terms.
\end{abstract}

Keywords - friction damper, non-linear time history analysis, response

\section{INTRODUCTION}

In the last 20-30 years, more and more buildings are equipped with special devices with the role of dissipating the energy induced in the structure during seismic events. Protective seismic devices are introduced to improve the structures response in terms of ductility or to take over most of the seismic energy [1].

The present paper presents the effect of position of friction damper on the seismic response of 2D frame structure in comparison with structures stiffened by large sections and centrally braced. Non-linear times-history analysis using Vrancea 1977 ground motion record scaled to $0.3 \mathrm{~g}$, (Figure 1) and two artificial accelerogram was performed for each structure (Figure 2, Figure 3).

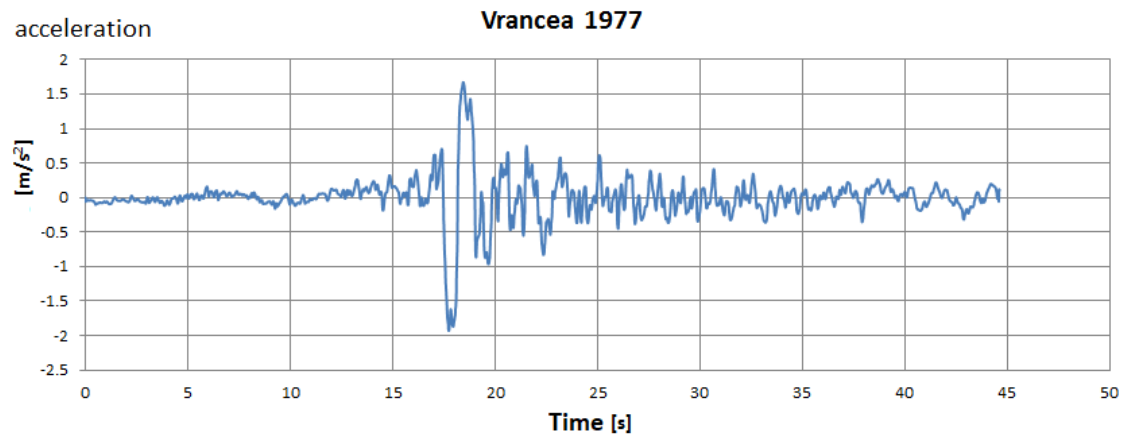

Fig. 1. Vrancea accelerogram 4 March 1977 
sciendo $_{108}$ Ovidius University Annals Series: Civil Engineering, Year 23, 2021

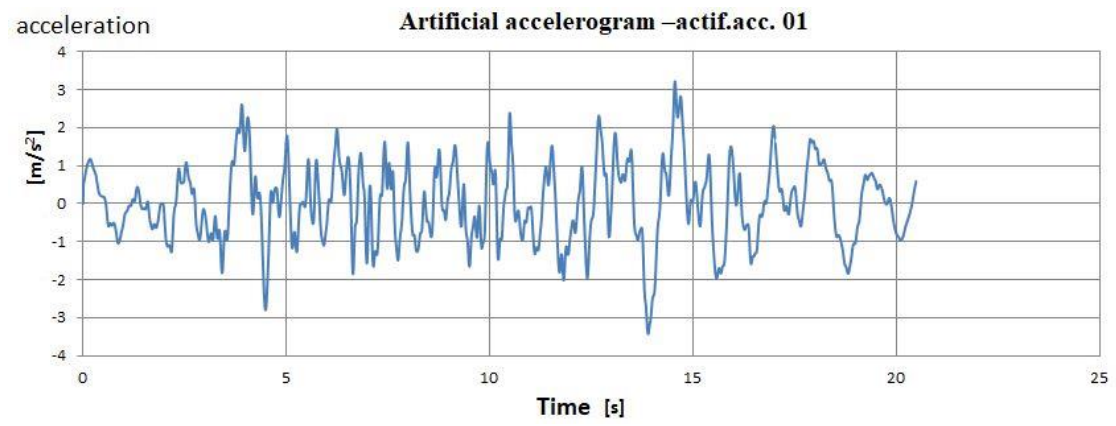

Fig. 2. Artificial accelerogram -actif.acc. 01

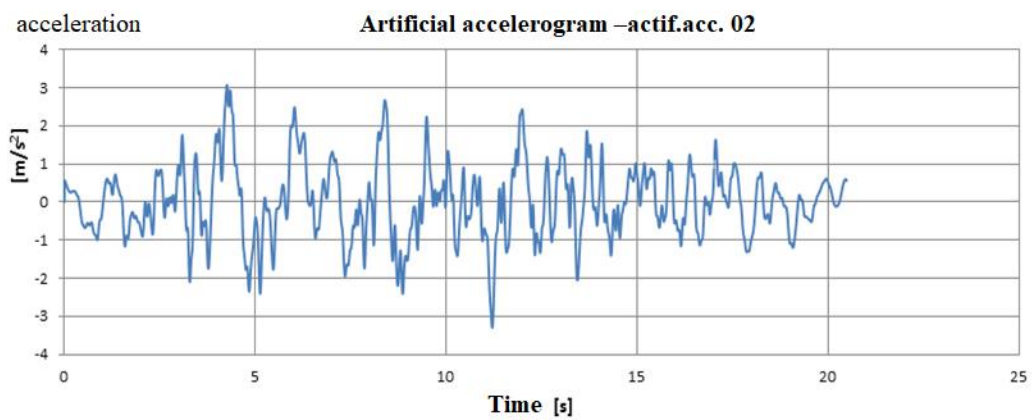

Fig. 3. Artificial accelerogram -actif.acc. 02

\section{EXPERIMENT DESCRIPTION}

In this case study, sets of analysez are performed to compare the seismic response of structures stiffened by large sections (Figure 3) with that of centrally braced structures (Figure 4) and structures equipped with friction dampers with a capacity of $50 \mathrm{KN}$ and 100 KN (Figure 5).

The analyzed structures have the following geometric characteristics: 5 openings of $6 \mathrm{~m}$, the ground floor has a height of $4,5 \mathrm{~m}$ and the rest of the levels have a height of $3,5 \mathrm{~m}$.

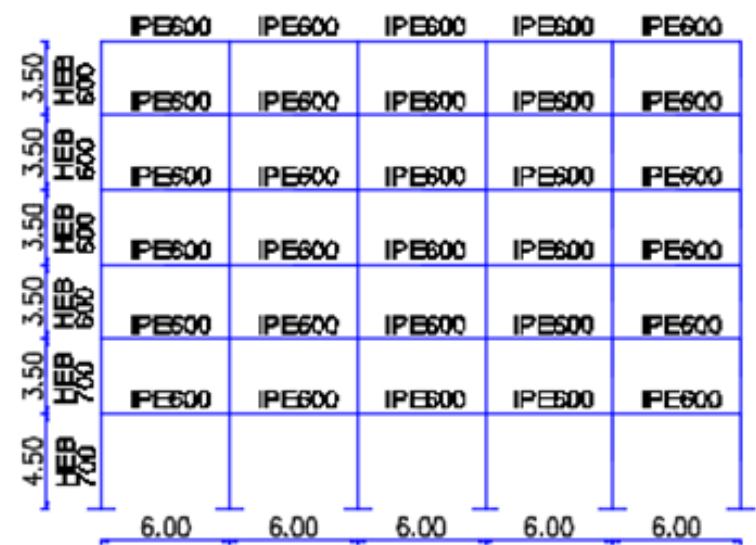

Fig. 3. Structures with 6 stiffened levels (Str. rig.) 


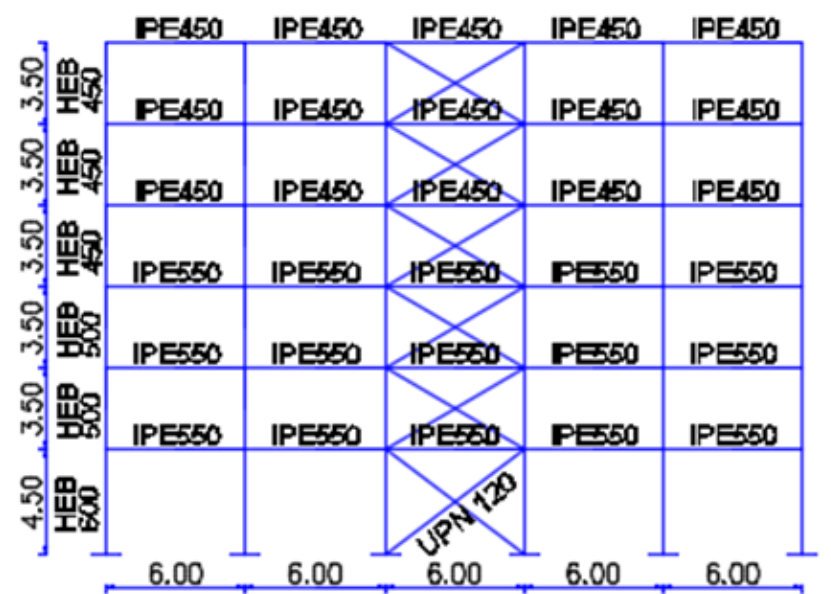

Fig. 4. Structure with 6 levels centrally braced (Str. cv.)

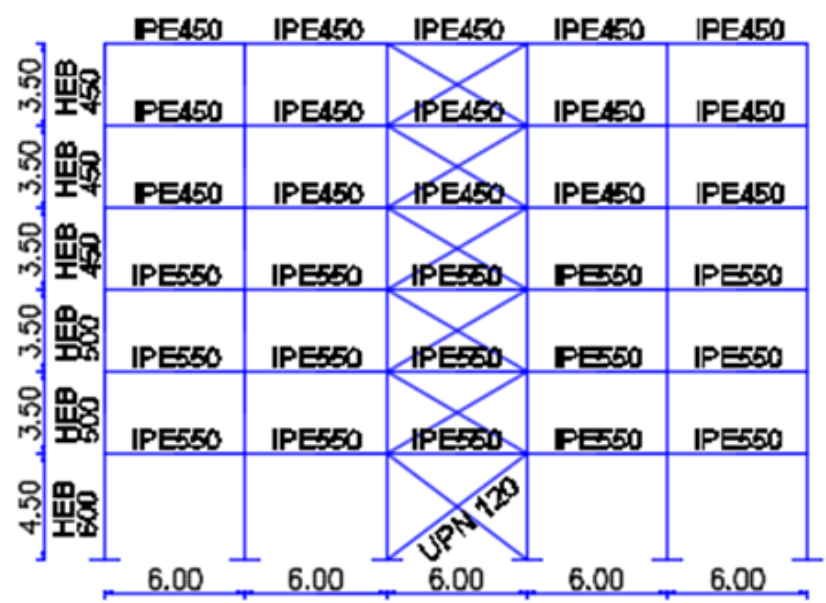

Fig. 5. Structure 6 levels equipped with friction dampers with a capacity of $50 \mathrm{KN} / 100 \mathrm{KN}$ (Str. am. $50 \mathrm{KN} / 100 \mathrm{KN})$

The program ETABS 17 [2] was used to assess the response of structures. Three design scenarios were taken into consideration for each of structures 6 levels.

\section{RESULTS AND SIGNIFICANCES}

An important parameter that reveals the seismic response of the structures is the relative level displacements. The percentage of relative level displacements being the main criterion that must be met in the seismic design of the structures. The relative level displacements of the 4 structures with 6 levels subject to the 3 accelerograms is presented in Figure 6.

It can be observed that the stiffening brought by braces but also the equipment of the structures with added damping leads to the reduction of the level displacements for the 3 accelerograms (Figure 6). The biggest reduction in terms of relative level displacements is found between the frame structure (str. rig.) and the braced structure (str.cv.) [3]. 


\section{sciendo}

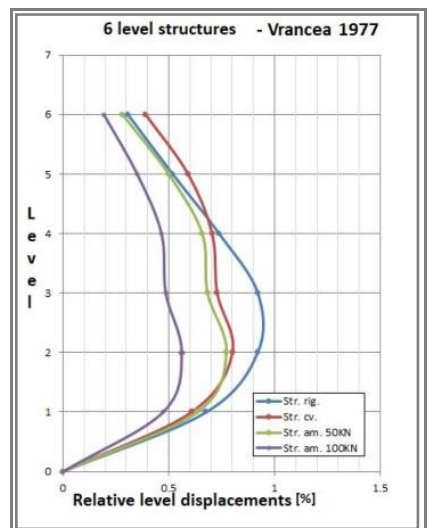

a)

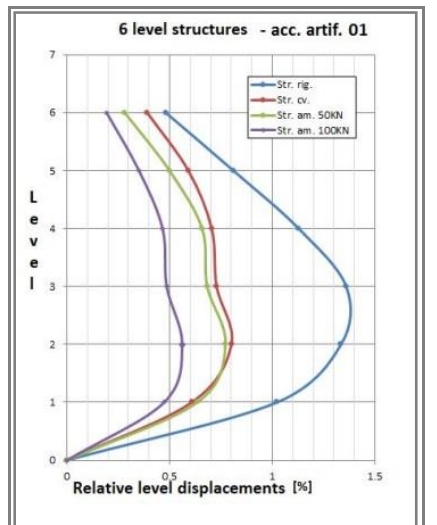

b)

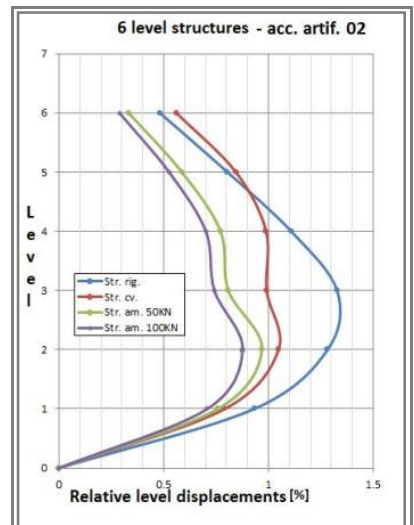

c)

Fig.6. Relative level displacements - 6-level structures for accelerograms: a)Vrancea 1977, b) Artificial 01, c) Artificial 02

Figure 7 shows the variation of the maximum displacements at the peak in the case of the 4 structures with six levels, for the three accelerograms. For the structures provided with friction dampers with a capacity of $50 \mathrm{KN}$ and $100 \mathrm{KN}$ (str. Am $50 \mathrm{KN}$ and str. Am. $100 \mathrm{KN}$ ), there is a phase shift of the maximum displacements from the frame structure and the centrally braced structure.
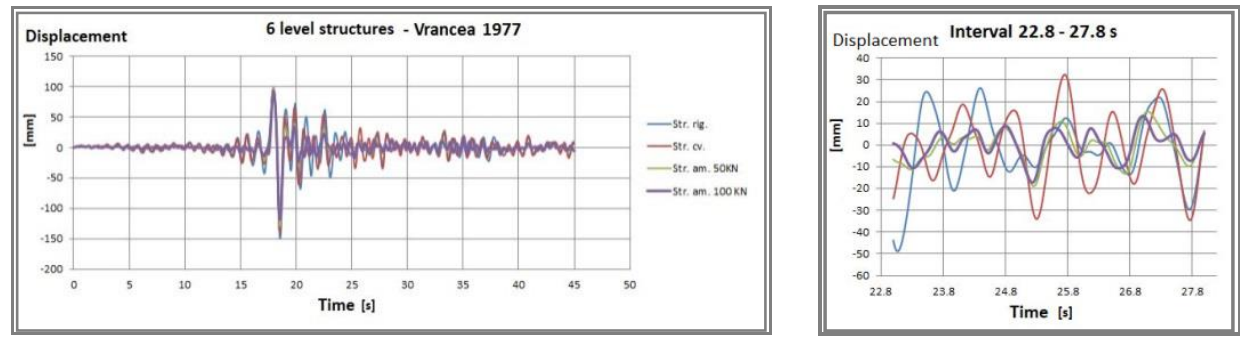

Fig.7. Variation of maximum displacements at the top - structures with 6 levels for the 1977 Vrancea accelerogram

Lateral level accelerations are a relevant indication in the study of the seismic response of structures located in regions with high seismicity. Figure 8 shows the variations of the lateral acceleration from the last level of the four structures analyzed by applying the 1977 Vrancea accelerogram.
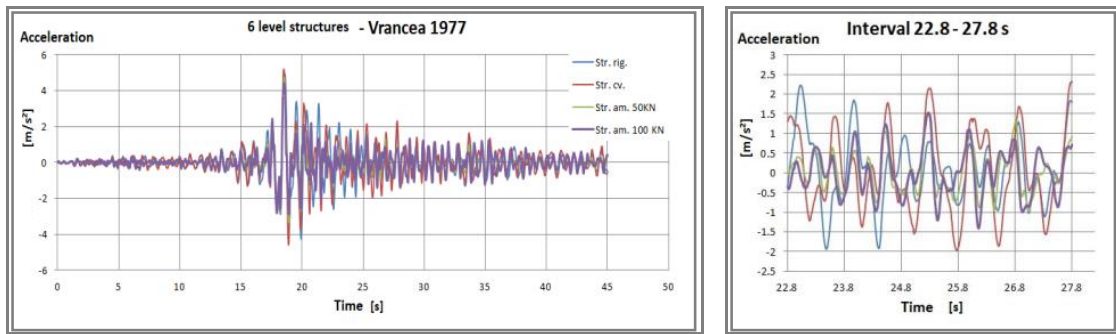

Fig.8 Variation of lateral acceleration at the last level - structures with 6 levels for the Vrancea accelerogram 1977 
For the 1977 Vrancea accelerogram, the maximum value of the lateral acceleration at the last level is recorded by the centrally braced structure (str.cv) and is $5.20 \mathrm{~m} / \mathrm{s}^{2}$, and the value minimum is registered in the case of the structure with dampers with a capacity of $100 \mathrm{KN}$ (str. am. 100KN) and is $4.41 \mathrm{~m} / \mathrm{s}^{2}$. There is practically a reduction of up to $15.20 \%$ of the value of the maximum acceleration atthe last level.

Following the study on the response in terms of maximum accelerations at the last level, there is a fairly high variability for the three accelerograms. The reduction of the seismic response is in the range of $15.20 \%-40.80 \%$.

The variation of the maximum basic seismic force in parallel with the maximum value of the maximum displacement the level is shown in Figure 9.

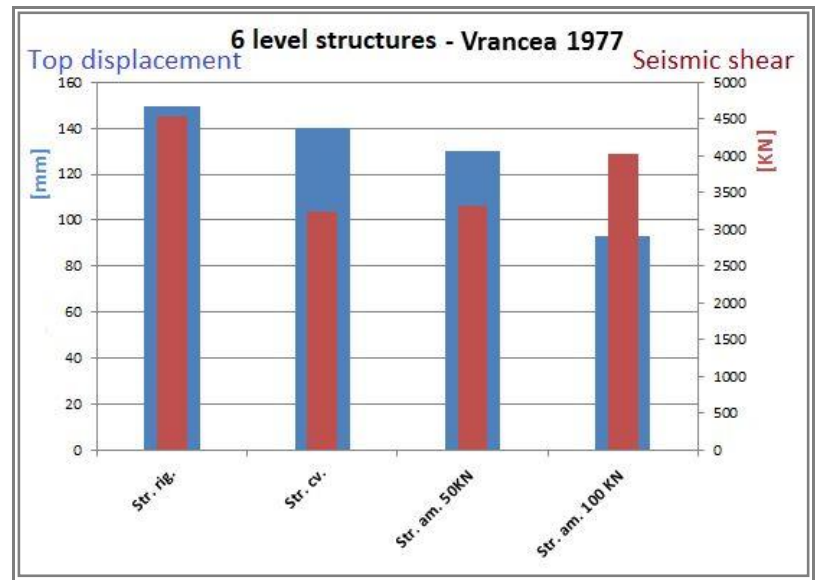

Fig.9. Variation of the maximum basic seismic shear force depending on the lateral rigidity - Vrancea1977

In the case of the structures subjected by the 1977 Vrancea earthquake, it is found that the basic seismic force with the highest value is recorded in the case of the frame structure. The structure equipped with $100 \mathrm{KN}$ friction dampers (str. Am. 100KN), although it registers the lowest displacement at the top, „benefits" from a basic shear force $19.55 \%$ higher than the braced structure and with $17.49 \%$ higher than the structure provided with $50 \mathrm{KN}$ shock absorbers (str. Am. 50KN) (Figure 9).

The study of the rigidity of the structures in parallel with the maximum value of the maximum basic seismic force for the structures with 6 levels analyzed shows us that there is no direct correlation between these two important parameters addressed in the classical design of structures [3].

\section{CONCLUSIONS}

This study shows that that placement of damper improve the structural response in terms of relative level displacements and lateral acceleration at the last level.

It is visible that structure equipped with friction dampers has the minimum response in terms of top roof displacement.

The study shows us that there is no direct correlation between the rigidity and maximum value of the maximum basic seismic force for the structures with 6 levels analyzed. 


\section{sciendo}

112 Ovidius University Annals Series: Civil Engineering, Year 23, 2021

\section{REFERENCES}

[1] Ghindea, C. L. - Studiul unor metode de atenuare a acțiunii seismice asupra structurilor, Teză de doctorat, Universitatea Tehnică de Construcții București, 2008

[2] https://www.csiamerica.com/products/etabs

[3] Oance, I.S. - Răspunsul seismic al structurilor în cadre contravântuite echipate cu amortizori cu frecare prin rotație, Teză de doctorat, Universitatea Ovidius din Constanța, 2021

[4] Văcărescu, N.G., Stratan, A., Dubină D. - Sisteme structurale disipative cu contravântuiri cu amortizori cu frecare: Studiu de soluţie şi comparaţie cu sistemele convenţionale- partea 1, Conferinţa Naţională de Construcţii Metalice, Bucureşti, 21-22 noiembrie 2013

[5] Cheng, F.Y.; Jiang, H.; Lou K. - Smart Structures: Innovative Systems for Seismic Response Control, ISBN 978-0-8493-8532-2, 2008

\section{Note:}

Ionut-Sergiu Oance - Ovidius University of Constanta, Doctoral School of Applied Sciences, Constanta, Romania, (corresponding author to provide e-mail: ionut_oance@yahoo.com)

Gelmambet Sunai - Ovidius University of Constanta, Bd. Mamaia nr.124, 900356, Constanta, Romania (e-mail: gelmambets@univ-ovidius.ro) 